\title{
The influence of single species populations of ciliates and multispecies fauna on pool size and outflow of microbial matter from the reticulo-rumen of sheep*
}

\author{
G. Belżecki ${ }^{1}$, R. Miltko and T. Michałowski \\ The Kielanowski Institute of Animal Physiology and Nutrition, \\ Polish Academy of Sciences \\ 05-110 Jabłonna, Poland
}

(Received 23 August 2012; revised version 14 November 2012; accepted 15 November 2012)

\begin{abstract}
The pool size of bacterial and protozoal matter in rumen fluid and the microbial matter passage rate to the omasum were determined in 3 sheep fed $750 \mathrm{~g}$ hay and $130 \mathrm{~g}$ ground barley every $12 \mathrm{~h}$. The animals were either ciliate free or selectively faunated with Eudiplodinium maggii, Diploplastron affine, Entodinium caudatum, or natural protozoal fauna. Murein $\beta$-glycans were used as a marker to quantify the bacterial matter, whereas the dry matter content of single ciliates and their number were used to calculate protozoal matter. It was found that the total bacterial matter in the rumen fluid of ciliate-free sheep was $216 \mathrm{~g}$ and the pool size arriving in the duodenum, $231 \mathrm{~g}$ dry matter (DM). The protozoal matter varied from 24 to $71 \mathrm{~g} \mathrm{DM}$ in the rumen fluid and from about 18 to $71 \mathrm{~g} \mathrm{DM}$ in omasal influent. The dry matter of ciliate-associated bacteria varied from 11 to $23 \mathrm{~g}$ in the rumen and from over 5 to $23 \mathrm{~g}$ in the omasal influent. The establishment of ciliates reduced the pool size of bacterial matter by $17 \%-39 \%$ in the rumen and by $20 \%-38 \%$ in the omasal influent.
\end{abstract}

KEY WORDS: rumen, bacteria, ciliates, murein, sheep

\section{INTRODUCTION}

Bacteria are the most numerous microorganisms inhabiting the rumen, i.e., the first and the largest chamber of the complex stomach in ruminants. The presence of a cell wall and its structure are specific features of these microorganisms.

\footnotetext{
* Supported by the Ministry of the Scientific Research and Information Technology, Grant No. 2P06Z05230

${ }^{1}$ Corresponding author: e-mail: g.belzecki@ifzz.pan.pl
} 
The main component of the bacterial cell wall is murein, which contributes to about 3\%-10\% and 20\%-60\% DM of Gram-negative and Gram-positive bacteria, respectively (Litzinger and Mayer, 2010). According to Ling (1990), murein consists of polysaccharide strands (glycans) cross-linked with short peptides. Each strand is composed of $\mathrm{N}$-acetylglucosamine and $\mathrm{N}$-acetylmuramic acid residues. Thus, murein could be considered a potential source of substrates in energy-yielding processes of rumen microorganisms capable of digesting and fermenting murein polysaccharides. On the other hand, King and White (1977) used the muramic acid in muramine to quantify microbial biomass in estuarine and marine ecosystems. Due to this, as we discussed in our previous paper (Bełżecki et al., 2012), there is the possibility of using murein structural polysaccharides as internal markers of bacterial matter in the reticulo-rumen. A similar role has been played for many years by DAPA, i.e. 2,6-diaminopimelic acid (El-Shazly and Hungate, 1966). It has been used most often to quantify bacterial protein in ruminal and duodenal digesta (Ling and Buttery, 1978; Broderick and Merchen, 1992). Some other authors, however, have used this marker to determine the pool size of bacterial matter (Michalowski, 1990; Martin et al., 1994; Pan et al., 2000) in sheep and cows.

Taking this into account, we undertook the current study. Its objectives were: 1. to quantify murein $\beta$-glycans in purified bacteria and in rumen fluid, 2 . to calculate the pool size of the bacterial matter associated with this fraction of rumen digesta using murein $\beta$-glycans as the marker, 3 . to quantify the protozoal matter in the rumen, 4 . to quantify the pool size of bacterial and protozoal matter passing from the reticuo-rumen into the omasum, and 5. to assess the influence of rumen fauna composition on the listed parameters.

\section{MATERIAL AND METHODS}

Animals, feeds and feeding

Three adult rams of the Żelazieńska breed weighing $86 \pm 5.3 \mathrm{~kg}$ and fitted with large rumen fistulae were kept in separate pens and fed every $12 \mathrm{~h}$ a diet consisting of meadow hay (750 g) and ground barley (130 g). Water was available ad libitum.

\section{Experimental}

The experimental design was described in detail by Bełżecki et al. (2012). Briefly, it consisted of 5 periods in the course of which the sheep were either protozoa free (period I) or selectively faunated with Eudiplodinium maggii (period II), Diploplastron affine (period III), Entodinium caudatum (period IV), 
and natural rumen fauna (period V). The ciliate-free sheep were prepared according to Michałowski et al. (1999), whereas the monofaunated animals (periods II, III and IV) were obtained by defaunation followed with inoculation of cultures of the particular ciliate species (see above) into the rumen of the hosts. The ciliates were isolated from the rumen of other sheep and maintained in vitro using a routine method (Michałowski, 1995). They were identified according to Dogiel (1927). Period V of experiment began with the faunation of all three rams with samples of rumen fluid taken from sheep possessing a natural rumen fauna.

\section{Sampling and counting}

Sampling followed the preliminary feeding period of sheep that always lasted three weeks (Jouany and Ushida, 1990) to allow the establishment of the population of bacteria and fungi that develop spontaneously after successive defaunation and refaunation of sheep, as well as of the protozoa that were inoculated according to the experimental design. Rumen and reticular fluids for microbial and chemical analysis were sampled just before the morning feeding and at 4, 8, and $12 \mathrm{~h}$ thereafter. Each sampling was repeated three times on three different days. The same animal was, however, sampled no more than 2 times a week. The samples for counting protozoa $(5 \mathrm{ml})$ were fixed with a $4 \%$ formaldehyde solution and stored at room temperature. The samples collected for chemical analysis $(100 \mathrm{ml})$ were lyophilized and stored at $-40^{\circ} \mathrm{C}$. The ciliates were counted as described in a previous paper (Bełżecki et al., 2012).

The rumen and reticular fluids were sampled using two separate metal probes equipped with a filter of 5-6 cm in length. It was tightly screwed to the end of the probe that was inserted into the reticulum or the rumen just before sampling. The wall of the filter was cross-bored with numerous pores of about $2 \mathrm{~mm}$ in diameter. The opposite end of each probe was connected to a $100 \mathrm{ml}$ syringe that enabled us to collect the examined material by suction.

\section{Preparation of purified suspension of protozoa and bacteria}

Samples of rumen fluid 11 in volume were used to prepare the purified suspensions of protozoa. The ciliates were separated from plant material and external bacteria by the repeated sedimentation and washing procedure according to Bełżecki et al. (2007). The suspension of well-purified ciliates containing a known number of cells was dried in a vacuum and then weighed. The obtained results were used to calculate the dry matter content of a single ciliate. The dried protozoa were stored at $-80^{\circ} \mathrm{C}$.

Bacteria were isolated according to Michałowski et al. (2003). The $500 \mathrm{ml}$ samples of rumen fluid were centrifuged at $600 \mathrm{~g}$ for $3 \mathrm{~min}$ to separate small 
particle and protozoa. The supernatant was collected and centrifuged at $30.000 \mathrm{~g}$ for $30 \mathrm{~min}$. The sediment was suspended in a cold water $\left(4^{\circ} \mathrm{C}\right)$ and centrifuged again. The washing procedure was repeated for several times. Finally the well washed sediment was lyophilized and stored at $-80^{\circ} \mathrm{C}$.

\section{Isolation and quantification of murein $\beta$-glycan}

Murein glycans were isolated according to Glauner (1988). Lyophilized bacteria ( $2 \mathrm{~g}$ ) were suspended in $50 \mathrm{ml}$ of ice-cold distilled water. The suspension was diluted up to 11 with a $4 \%$ solution of sodium dodecyl sulphate (SDS) and boiled for $30 \mathrm{~min}$. The murein polysaccharides forming small vesicles were separated by centrifugation at $100000 \mathrm{~g}$ for 30 min followed by washing with distilled water. The washing procedure was repeated until complete removal of SDS. Finally, the saccharides were collected, lyophilized and stored at $-40^{\circ} \mathrm{C}$.

The murein polysaccharides present in bacteria, protozoa, as well as in the rumen fluid and reticular effluent were measured by quantification of the lactic acid released from the substrate as a result of acidic hydrolysis (King and White, 1977; Bełżecki et al., 2012).

\section{Measurement of rumen fluid and omasal influent volumes}

The measurements were done according to Hyden (1961) using polyethylene glycol (PEG) with a molecular weight 4000 as a marker of the examined fluids. A $100 \mathrm{ml}$ dose of aqueous 10\% PEG was poured into the rumen of sheep and $100 \mathrm{ml}$ samples of rumen and reticular fluid were collected to determine its concentration in the examined material. The first sample was always withdrawn just before PEG infusion and the next at 1, 2, 4, 6, 8, 10, and $12 \mathrm{~h}$ thereafter. The collected material was sub-sampled for the counting of protozoa $(2 \times 5 \mathrm{ml})$ and to measure the marker concentration (about $50 \mathrm{ml}$ ). The remainder was replaced in the rumen.

The concentration of PEG in rumen and reticulum fluid was determined according to Hyden (1961). In brief, samples of both fluids were filtered through filter paper (Whatman No. 1) and deproteinized by treatment with a solution consisting $9.5 \% \mathrm{Ba}(\mathrm{OH})_{2}, 10 \% \mathrm{BaCl}_{2}$, and $5 \% \mathrm{ZnSO}_{4}$. PEG was precipitated with $30 \%$ trichloroacetic acid (TCA) in $5 \% \mathrm{BaCl}_{2}$ and the optical density of the suspension was measured spectrophotometrically at $600 \mathrm{~nm}$ using a Beckman DU-64 spectrophotometer. The obtained results were compared with a standard curve to calculate the content of polyethylene glycol in the examined samples.

The rumen fluid volume at the start of experiment as well as its volume into the omasum during $12 \mathrm{~h}$ after feeding were calculated from the followng equations of Hyden (1961): 


$$
\mathrm{V}=\mathrm{M} / \mathrm{Co} \text { and } \mathrm{Vf}=0.693 / \mathrm{V} / \mathrm{T}
$$

where: $\mathrm{V}$ - the rumen fluid volume at the start of measurement; $\mathrm{M}$ - the marker (PEG) dose, $\mathrm{Co}$ - the initial concentration of marker in the rumen fluid; Vf - the volume of fluid flowing out the rumen during $12 \mathrm{~h}, \mathrm{~T}-$ the time of lowering the marker concentration by $50 \%$.

The volume of the liquid fraction flowing from the reticulum into the omasum was calculated from the equation:

$$
\mathrm{Ve}=\mathrm{Vfk}+\mathrm{Vp}
$$

where: Ve - the volume of the liquid fraction passing into the omasum during $12 \mathrm{~h}$; $\mathrm{k}$ - the correction factor calculated on the basis of marker concentration in the rumen and reticular fluids, $\mathrm{Vp}$ - the volume of particulate matter in the reticular effluent.

$\mathrm{Vp}$ was calculated from the volume of reticular effluent and the volume of its liquid fraction obtained by centrifugation at $26000 \mathrm{~g}$ for $30 \mathrm{~min}$.

\section{Calculations and statistical analysis}

The results of analysis of each sample taken from the rumen on each collection day were used to calculate the overall mean values regarding each animal and each examined parameter. The overall means calculated separately for 3 animals were then used to calculate the treatment means $(n=3)$. Similar calculations were performed in relation to the reticulo-rumen effluent. The treatment means were compared statistically using Student's t-test to characterize the influence of protozoa on the examined parameters. All of the statistical calculations were done according to Parker (1979).

\section{RESULTS AND DISCUSSION}

The mean results of the quantification of murein polysaccharides in bacteria are presented in Figure 1. They contributed to $16.1 \%-22.5 \%$ of bacterial DM. These findings are in good accordance with the data of Litzinger and Mayer (2010) concerning the proportion of murein in bacterial DM. The concentration of the examined carbohydrates was significantly higher in the defaunated sheep in comparison with those faunated with a single species of ciliates, as well as with multispecies fauna. The one of the possible explanations for this relationship could be the decrease in the proportion of Gram-positive bacteria containing much more murein than Gram-negative species (Litzinger and Mayer, 2010) due to the preferential ingestion of the former by rumen protozoa (Coleman and Hall, 1972; 


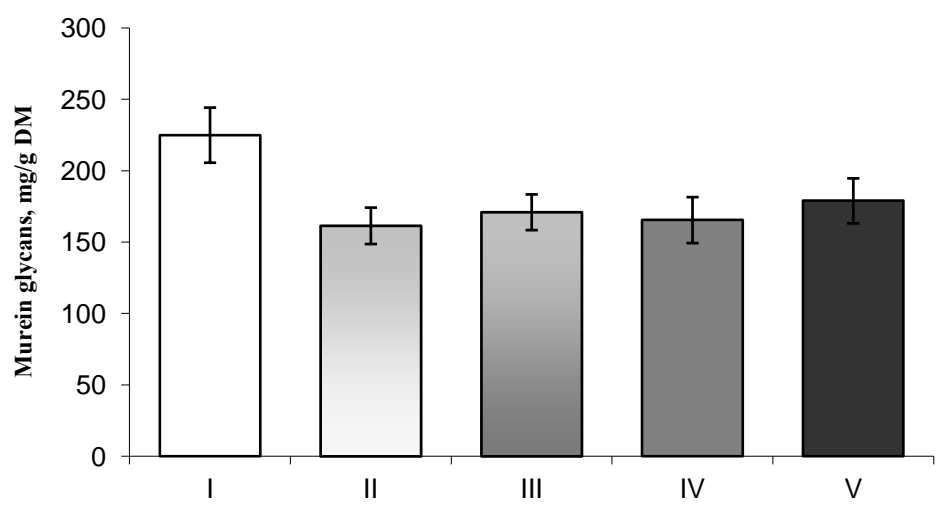

Figure 1. The murein glycan concentration in bacteria (mg/g DM) isolated from the rumen in particular periods of experiment. Defaunated sheep (I) and the sheep refaunated with Eudiplodinium maggii (II), Diploplastron affine (III), Entodinium caudatum (IV) and multispecies ciliate fauna (V)

Ushida et al., 1987). Whitelaw et al. (1972), however, did not observe selective bacteria engulfment under in vivo conditions. On the other hand, the cell wall of some Gram-negative species resembles that of Gram-positive ones in terms of murein content (Stewart et al., 1997). Thus, more detailed studies on bacterial flora seem to be necessary to explain the observed phenomenon.

The dry matter (DM) and murein carbohydrate contents of the representatives of particular groups of ciliates are presented in Table 1. These data show that the DM of single E. caudatum cells was by about 6 and 19 times lower in comparison with $D$. affine and E. maggii, respectively. The species of ciliates examined here represent the small, medium, and large protozoa in the rumen (Michałowski, 1990). The small protozoa, like E. caudatum, dominated in the rumen in the course of last period of experiment and due to this, perhaps, the DM of a single representative of the multispecies fauna was only two times greater than of E. caudatum.

Table 1. Dry matter and murein carbohydrate content in ciliates isolated from the rumen of selectively faunated sheep (ng/cell). Mean values ( $\mathrm{n}=3$ )

\begin{tabular}{lcc}
\hline Protozoa group & Dry matter & Murein \\
\hline Eudiplodinium maggii & $196.5 \pm 21.27$ & $9.8 \pm 2.14$ \\
Diploplastron affine & $66.1 \pm 9.76$ & $6.4 \pm 2.05$ \\
Entodinium caudatum & $10.4 \pm 3.45$ & $1.1 \pm 0.38$ \\
Multispecies ciliate fauna & $20.7 \pm 5.8$ & $1.2 \pm 0.65$ \\
\hline
\end{tabular}

The data presented in Table 2 characterize the influence of ciliates on important parameters of the reticulo-rumen ecosystem. The results show that the establishment of ciliates in the rumen increased the rumen fluid volume by 
about $18 \%$. These results are consistent with previous studies by Bełżecki and Michałowski (2005). They disagree, however, with the findings of Orpin and Letcher (1984), who observed an increase in the rumen fluid volume following defaunation of sheep. Conversely to our own results and to the data of the cited authors, Ushida (1986) observed no influence of protozoa on rumen fluid volume. The obtained results also show that the composition of rumen fauna had no effect on rumen fluid volume despite the great difference between the concentrations of ciliates (Bełżecki et al., 2012), as well as between their total number and biomass in the rumen. Further studies are thus necessary to elucidate this phenomenon.

Table 2. The characteristics of microbial reticulo-rumen ecosystem of ciliate free sheep (I) and sheep faunated with Eudiplodinium maggii (II), Diploplastron affine (III), Entodinium caudatum (IV) and a natural fauna $(\mathrm{V})$. Mean values $(\mathrm{n}=3)$

\begin{tabular}{lccccc}
\hline \multirow{2}{*}{ Indices } & \multicolumn{5}{c}{ Periods of experiment } \\
\cline { 2 - 6 } & I & II & III & IV & V \\
\hline Rumen fluid & & & & & \\
$\quad$ rumen fluid volume, 1 & $8.9^{\mathrm{a}}$ & $10.5^{\mathrm{b}}$ & $10.1^{\mathrm{b}}$ & $10.5^{\mathrm{b}}$ & $10.3^{\mathrm{b}}$ \\
total protozoa, x 10 & 0 & $1.9^{\mathrm{a}}$ & $5.2^{\mathrm{b}}$ & $23.5^{\mathrm{c}}$ & $34.4^{\mathrm{d}}$ \\
protozoal DM, g & 0 & $37.3^{\mathrm{a}}$ & $34.4^{\mathrm{a}} \pm 35.6^{\mathrm{a}}$ & $24.4^{\mathrm{a}} \pm 23.9^{\mathrm{a}}$ & $71.2^{\mathrm{b}} \pm 63.8^{\mathrm{b}}$ \\
total DM of bacteria, g & $216^{\mathrm{a}}$ & $180^{\mathrm{b}}$ & $175^{\mathrm{c}}$ & $167^{\mathrm{c}}$ & $132^{\mathrm{c}}$ \\
DM of ciliate associated bacteria, g & 0 & $11.3^{\mathrm{a}}$ & $19.5^{\mathrm{b}}$ & $15.7^{\mathrm{c}}$ & $23.1^{\mathrm{d}}$ \\
Reticulo-rumen effluent & & & & & \\
reticular effluent volume, 1/12 h & $11.6^{\mathrm{a}}$ & $12.4^{\mathrm{a}}$ & $12.1^{\mathrm{a}}$ & $12.6^{\mathrm{a}}$ & $12.2^{\mathrm{a}}$ \\
total protozoa, 10 & 0 & $0.9^{\mathrm{a}}$ & $3.9^{\mathrm{b}}$ & $27.6^{\mathrm{c}}$ & $34.2^{\mathrm{c}}$ \\
protozoal DM, g & 0 & $17.7^{\mathrm{a}}$ & $25.8^{\mathrm{b}}$ & $28.7^{\mathrm{b}}$ & $70.8^{\mathrm{c}}$ \\
total DM of bacteria, g & $231^{\mathrm{a}}$ & $186^{\mathrm{b}}$ & $182^{\mathrm{b}}$ & $158^{\mathrm{c}}$ & $143^{\mathrm{c}}$ \\
DM of ciliate associated bacteria, g & 0 & $5.2^{\mathrm{a}}$ & $14.6^{\mathrm{b}}$ & $18.4^{\mathrm{c}}$ & $22.9^{\mathrm{d}}$ \\
\hline
\end{tabular}

values with different superscripts differ significantly at $\mathrm{P}<0.05$

We found that 11.6-12.5 1 of reticular fluid flowed into the omasum during the $12 \mathrm{~h}$ after the morning feeding and did not depend on the presence of ciliates in the rumen. The comparison of relevant data presented in Table 2 shows that the volume of the omasal influent was equal to $120 \%-130 \%$ of the rumen fluid volume observed just before the morning feeding. The same data also show that the turnover rate of the liquid fraction of rumen content was in the range of 2.4-2.6 per $24 \mathrm{~h}$. These figures correspond with the earlier findings of Michałowski (1990). It was also found that establishment of ciliates in the rumen of sheep resulted in a decrease in the turnover rate of rumen fluid $(\mathrm{P}<0.05)$ and a similar relationship was observed by Miltko (2011).

The most important parameters of microbial populations of the liquid fraction of rumen digesta and of the omasal influent were calculated on the basis of the volume of both fluids and on the concentration of ciliates, dry matter content in a single protozoa cell, or on the murein glycan contents in purified bacteria. The total number of protozoa varied from $1.9 \times 10^{8}$ to over $34.4 \times 10^{8}$ and was the 
smallest when only E. maggii ciliates were present in the rumen, and the greatest after development of the natural rumen fauna. The protozoal matter varied from 24.4 to $71.2 \mathrm{~g}$ DM. It was the smallest in sheep faunated with E. caudatum (period IV) and the largest, in animals having well-developed multispecies rumen fauna (period V). The observed relationship could be explained by the difference between the mean DM content per cell of the protozoa present in the rumen in the particular periods, as well as between their total number (Tables 1 and 2).

Bacteria counts were not determined in this study, but their dry matter varied from 132 to $216 \mathrm{~g}$. These results are in accordance with the findings of Michalowski (1990) who stated that the DM of bacteria varied from about $98 \mathrm{~g}$ to over $180 \mathrm{~g}$ /total volume of rumen fluid in growing sheep fed $300 \mathrm{~g}$ hay and $350 \mathrm{~g}$ concentrate every $12 \mathrm{~h}$. It is important to note that bacterial matter was quantified there using DAPA as the internal bacterial marker. The same marker was used by Pan et al. (2000) to determine the bacterial matter in whole rumen digesta of sheep fed once daily with orchard or lucerne hay. The cited authors have, however, found that the bacterial matter varied from about $190 \mathrm{~g}$ to $497 \mathrm{~g}$. The difference between our findings and the results cited above could, perhaps, be explained by the fact that the majority of rumen bacteria is associated with feed particles (Czerkawski, 1986).

The results presented in Table 2 show that the establishment of ciliates in the rumen of sheep decreased bacterial matter by $17 \%-33 \%$ in comparison with the ciliate-free animals. The largest drop was observed when either multispecies fauna (33\%) or E. caudatum (23\%) were present in the rumen. In both discussed periods, the small ciliates either dominated or were the only ciliates in the rumen of sheep. Thus, the relationships observed in periods IV and V of the study confirm the important impact of small protozoa on the turnover of bacterial matter in the rumen and are in agreement with the opinion of Coleman (1988).

The combined biomass of protozoa and bacteria was 191-217 g per rumen and the latter contributed there to $12.7 \%-35 \%$. These results are in good agreement with the findings of Michałowski (1990). The biomass of bacteria associated with protozoa cells varied from $11.3 \mathrm{~g}$ to $23.1 \mathrm{~g}$ per total rumen fluid volume and was the lowest when only E. maggii ciliates became established in the rumen, and the highest when multispecies ciliate fauna developed there. The discussed values characterize perhaps the common biomass of engulfed bacteria as well as of those tightly associated with the surface of ciliate cells and of the endosymbiotic species. The data presented in Table 2 also show that the bacteria associated with protozoa cells contributed to $5 \%-11 \%$ of the total biomass of bacteria and to $30.3 \%-64.3 \%$ of the biomass of protozoa. These last figures show the important contribution of the mentioned bacteria to the total protozoal matter in the rumen.

The pool size of the bacterial mass leaving for the reticulo-rumen of ciliatefree sheep was $231 \mathrm{~g}$ per $12 \mathrm{~h}$. The establishment of the population E. maggii 
and $D$. affine reduced this pool by about $20 \%$ and $22 \%$, respectively, whereas this reduction reached $32 \%$ and $38 \%$ when only E. caudatum (period IV) or multispecies fauna (period V) were present in the rumen. These results show that the rumen fauna composition was the factor affecting the pool size of bacterial matter passing from the reticulo-rumen to the omasum.

The total number of ciliates passing into the omasum varied from $0.9 \times 10^{8}$ (E. maggii) to $34.2 \times 10^{8}$ (multispecies fauna) per $12 \mathrm{~h}$ and partially reflected their number in the rumen. It is, however, noteworthy that $E$. maggii and $D$. affine ciliates contributed only to $47.3 \%$ and $75 \%$ of their total number in the rumen before the morning feeding, whereas E. caudatum and representatives of multispecies fauna contributed $117.4 \%$ and $99.4 \%$, respectively. This phenomenon probably reflects the difference in the residence time of ciliates in the rumen (Michałowski et al., 1986). It is also worth emphasizing that the concentration of ciliates in the reticular fluid was used to calculate their total number passing down to the omasum. The basis for such an approach was the findings of Harmeyer and Michałowski (1991) showing no differences between the concentration of protozoa in the reticular fluid and in the fluid collected from the omasum just below the reticulum-omasum orifice.

The total biomass of bacteria passing into the omasum, expressed as DM, varied from 143 to $231 \mathrm{~g} / 12 \mathrm{~h}$, and was positively correlated with their mass in the rumen. It was the largest in defaunated sheep and the smallest in animals faunated with multispecies ciliate fauna. The establishment of the population of E. maggii or D. affine decreased the total pool of bacterial matter by $18 \%$ and $21 \%$, respectively. Conversely, the faunation of sheep with E. caudatum or multispecies fauna resulted in a drop in the total biomass of bacteria by $34 \%$ or $39 \%$, compared with the ciliate-free animals. These findings show that the pool size of bacterial matter arriving in the omasum clearly depended on the composition of ciliate fauna.

The pool size of bacterial matter associated with the protozoa present in the reticulo-rumen effluent varied from 5.2 (E. maggii) to $22.9 \mathrm{~g}$ (multispecies fauna) per $12 \mathrm{~h}$. They contributed to $29.3 \%$ of the total protozoal matter of E. maggii, but as much as $56.6 \%, 64.1 \%$, and $67 \%$ of $D$. affine, E. caudatum, and multispecies fauna, respectively. It can not be excluded that these data characterize the difference between the intensity of engulfment of bacteria by the examined protozoa. This suggestion needs, however, to be confirmed experimentally.

The common bacterial and ciliate matter arriving in the omasum varied between $186.7 \mathrm{~g}$ (period IV) and $213.8 \mathrm{~g}$ per $12 \mathrm{~h}$ and protozoa contributed there to $8.7 \%$, $12.4 \%$, and $15 \%$ of it when only E. maggii, D. affine, or E. caudatum were present in the rumen, respectively. They reached, however, 33\% when multispecies fauna was established there. This last figure suggests that the contribution of protozoa to the total microbial matter leaving for the reticulo-rumen of the host animals may depend on the fauna composition. 


\section{CONCLUSIONS}

The performed study confirmed the negative effect of ciliates on the pool size and outflow of bacterial matter from the reticulo-rumen. On the other hand, the composition of ciliate fauna influenced the pool size of protozoal and bacterial matter passing down to the omasum. Comparison of the results obtained in the reported study with the literature data characterizing the pool size of bacterial matter calculated on the basis of the concentration of 2,6-diaminopimelic acid seems to confirm the usefulness of murein carbohydrates as a marker of bacterial matter in the rumen and in the reticular effluent. This natural marker also seems to be useful in determination of the pool size of bacterial matter associated with the cells of protozoa.

\section{REFERENCES}

Bełżecki G., Michałowski T., 2005. Effect of selected rumen fauna on the digestion of starch and outflow of $\alpha$-glucose polymers from the reticulo-rumen of sheep. J. Anim. Feed Sci. 14, Suppl. $1,215-218$

Bełżecki G., Miltko R., Kwiatkowska E., Kowalik B., Michałowski T., 2012. The effect of ciliate fauna composition on murein content and mureinolytic activity in the rumen of sheep. J. Anim. Feed Sci. 21, 65-76

Bełżecki G., Newbold C.J., McEwan N.R., McIntosh F.M., Michałowski T., 2007. Characterization of the amylolytic properties of the rumen ciliate protozoan Eudiplodinium maggii. J. Anim. Feed Sci. 16, 590-606

Broderick G.A., Merchen N.R., 1992 Markers for quantifying microbial protein synthesis in the rumen. J. Dairy Sci. 75, 2618-2632

Coleman G.S., 1988. Protozoal-bacterial interaction in the rumen. In: J.V. Nolan, R.A. Leng, D.I. Demeyer (Editors). The Roles of Protozoa and Fungi in Ruminant Digestion. Penambul Books. Armidale (Australia), pp. 13-27

Coleman G.S., Hall F.J., 1972. Fine structural studies on digestion of bacterial species in the rumen ciliate, Entodinium caudatum. Tissue Cell 4, 37-48

Czerkawski J.W., 1986. An Introduction to Rumen Studies. Pergamon Press. Oxford

Dogiel V.A., 1927. Monographie der Familie Ophryoscolecidae. Arch. Protistenk. 59, 1-288

El-Shazly K., Hungate R.E., 1966. Method for measuring diaminopimelic acid in total rumen contents and its application to the estimation of bacterial growth. Appl. Environ. Microbiol. 14, 27-30

Glauner B., 1988. Separation and quantification of muropeptides with high-performance liquid chromatography. Anal. Biochem. 172, 451-464

Harmeyer J., Michałowski T., 1991. A technique for the collection of reticular effluent of sheep. J. Vet. Med. A 38, 107-114

Hyden S., 1961. The use of reference substance and the measurement of flow in the alimentary tract. In: D. Lewis (Editor). Digestive Physiology and Nutrition of the Ruminants. Butterworths. London, pp. 35-47

Jouany J.P., Ushida K., 1990. Protozoa and fiber digestion in the rumen. In: S. Hoshino, R. Onodera, H. Minato, H. Itabashi (Editors). The Rumen Ecosystem. The Microbial Metabolism and its Regulation. Japan Scientific Society Press and Springer-Verlag. Berlin, pp. 139-150

King J.D., White D.C., 1977. Muramic acid as a measure of microbial biomass in estuarine and marine samples. Appl. Environ. Microbiol. 33, 777-783 
Ling J.R., 1990. Digestion of bacterial cell walls in the rumen. In: S. Hoshino, R. Onodera, H. Minanto, H. Itabashi (Editors). The Rumen Ecosystem. The Microbial Metabolism and its Regulation. Japan Scientific Society Press and Springer-Verlag. Berlin, pp. 83-90

Ling J.R., Buttery P.J., 1978. The simultaneous use of ribonucleic acid, ${ }^{35}$ S, 2,6-diaminopimelic acid and 2-aminoethylphosphonic acid as markers of microbial nitrogen entering the duodenum of sheep. Brit. J. Nutr. 39, 165-179

Litzinger S., Mayer C., 2010. The murein sacculus. In: H. König, H. Claus, A. Varma (Editors). Prokaryotic Cell Wall Compounds: Structure and Biochemistry. Springer. Berlin, pp. 3-52

Martin C., Williams A.G., Michalet-Doreau B., 1994. Isolation and characteristics of the protozoal and bacterial fractions from bovine ruminal contents. J. Anim. Sci. 72, 2962-2968

Michałowski T., 1990. The synthesis and turnover of the cellular mater of ciliates in the rumen. Acta Protozool. 29, 47-72

Michałowski T., 1995. The influence of cellulose, starch and different sources of nitrogen on the growth of rumen ciliate protozoon Epidinium ecaudatum in vitro. J. Anim. Feed Sci. 4, 255-261

Michałowski T., Bełżecki G., Kwiatkowska E., Pająk J.J., 2003. The effect of selected rumen fauna on fibrolytic enzyme activities, bacterial mass, fiber disappearance and fermentation pattern on sheep. J. Anim. Feed Sci. 12, 45-64

Michałowski T., Harmeyer J., Bełżecki G., 1999. The importance of washing the omasum for successful defaunation of sheep. J. Anim. Feed Sci. 8, 611-619

Michałowski T., Harmeyer H., Breves G., 1986. The passage of protozoa from the reticulo-rumen through the omasum of sheep. Brit. J. Nutr. 65, 625-634

Miltko R., 2011. The chitinolytic property of ciliates Eudiplodinium maggii and their contribution to the metabolism of chitin in the rumen (in Polish). PhD. Thesis. The Kielanowski Institute of Animal Physiology and Nutrition. PAS. Jabłonna

Orpin C.G., Letchen A.J., 1984. Effect of absence of ciliate protozoa on rumen fluid volume, flow rate and bacterial populations in sheep. Anim. Feed Sci. Tech. 10, 145-153

Pan J., Suzuki T., Ueda K., Tanaka K., Okubo M., 2000. Diurnal changes in the distribution of ruminal bacteria attached to feed particles in sheep fed hay once daily. Asian-Austr. J. Anim. Sci. 13, $1708-1716$

Parker R.E., 1979. Introductory Statistics for Biology. 2nd Edition. Edward Arnold. London

Stewart C.S., Flint H.J., Bryant M.P., 1997. The rumen bacteria. In: P.N. Hobson, C.S. Stewart (Editors). The Rumen Microbial Ecosystem. $2^{\text {nd }}$ Edition. Blackie Acad. Profess. London, pp. $10-72$

Ushida K., 1986. Studies on protozoal contribution to the ruminant digestion PhD. Thesis. Tokyo University

Ushida K., Kaneko Y., Kojima Y., 1987. Effect of presence of large entodiniomorph protozoa on the rumen bacterial flora, fauna composition of small entodinia and in vitro cellulolysis and xylanolysis. Jpn. J. Zoot. Sci. 58, 893-902

Whitelaw F.G., Eadie J.M., Mann S.0., Reid. R.S., 1972. Some effects of rumen ciliate protozoa in cattle given restricted amounts of a barley diet. Brit. J. Nutr. 27, 425-437 